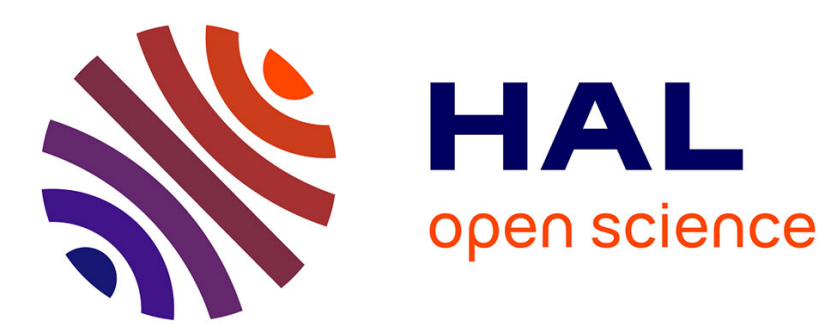

\title{
Visible minorities and Racially Mixed Conjugal Unions in Canadian Large cities
}

Dana Hamplova, Celine Le Bourdais

\section{To cite this version:}

Dana Hamplova, Celine Le Bourdais. Visible minorities and Racially Mixed Conjugal Unions in Canadian Large cities. Ethnic and Racial Studies, 2010, PP (PP), pp.1519-1542. 10.1080/01419871003743405 . hal-00589677

\section{HAL Id: hal-00589677 https://hal.science/hal-00589677}

Submitted on 30 Apr 2011

HAL is a multi-disciplinary open access archive for the deposit and dissemination of scientific research documents, whether they are published or not. The documents may come from teaching and research institutions in France or abroad, or from public or private research centers.
L'archive ouverte pluridisciplinaire HAL, est destinée au dépôt et à la diffusion de documents scientifiques de niveau recherche, publiés ou non, émanant des établissements d'enseignement et de recherche français ou étrangers, des laboratoires publics ou privés. 


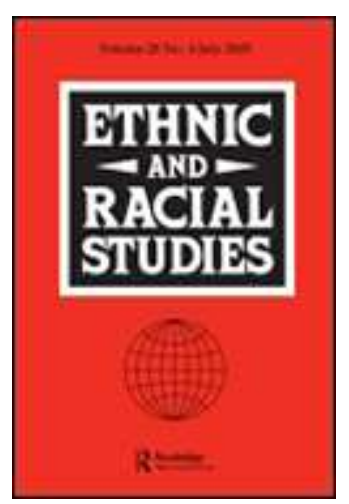

\section{Visible minorities and Racially Mixed Conjugal Unions in Canadian Large cities}

\begin{tabular}{|r|l|}
\hline Journal: & Ethnic and Racial Studies \\
\hline Manuscript ID: & RERS-2009-0108.R3 \\
\hline Manuscript Type: & Original Manuscript \\
\hline Keywords: & $\begin{array}{l}\text { racial intermarriage, visible minority, homogamy, assortative } \\
\text { mating, Canada, Language }\end{array}$ \\
\hline
\end{tabular}

\section{s ScholarONE" \\ Manuscript Central}




\title{
Visible minorities and 'White' - 'non-White' Conjugal Unions in Canadian Large cities
}

\begin{abstract}
The study investigates assortative mating patterns with respect to race (visible minority status) in Canada. Using the 2001 Census data, the article analyses the occurrence of White/non-White unions in Montreal, Toronto, and Vancouver. Log-linear models indicate that the relative levels of interracial relationships vary across racial groups, immigration status, and place of residence. First, the highest odds of cohabiting or marrying a White person are found among Blacks. Whereas the high level of racial exogamy of Blacks is observed in all metropolitan areas under study, the relative position of other groups varies. Second, the highest levels of racial exogamy are found among couples comprising an immigrant and a nonimmigrant but this effect varies across racial groups. Third, our hypothesis that residents of Montreal (Quebec) will interpartner less was confirmed only for unions between two native born Canadians. Finally, we found that French Canadians are not more inclusive of their linguistic counterparts than Anglophones.
\end{abstract}

Key words: racial intermarriage, visible minority, Canada, homogamy, assortative mating, interracial 


\section{AUTHORS:}

Dana Hamplová, Céline Le Bourdais

\section{ACKNOWLEDGEMENTS:}

The analysis is based on research carried out in the Quebec Inter-University Centre for Social Statistics, which provides researchers with access to detailed longitudinal survey data collected by Statistics Canada. The opinions expressed here do not represent the views of Statistics Canada. Support for this research was provided by the Social Science and Humanities Research Council and the McGill Canada Research Chair on Social Statistics and Family Change. 
Levels of interracial, interethnic, or intercultural marriage are commonly used to describe the openness of societies and the degree of equality among people of various ethnic, racial, or cultural origins. The extent to which members of different racial and ethnic groups marry each other demonstrates group boundaries, social distance, and acceptance of minorities (Qian and Lichter, 2007, Tzeng, 2000, Kalbach, 2002). Some authors even argue that ethnic/racial intermarriage is the single best indicator of minority assimilation (Gordon, 1964, Lee and Boyd, 2008) or that mixed unions are 'an engine of social change' (Milan and Hamm, 2004).

Most previous research on interracial mating analysed the situation in the United States (Fu et al., 2001, Qian and Lichter, 2001, Qian, 1997, Qian and Cobas, 2004, Harris and Ono, 2005, Model and Fisher, 2002). In contrast, we know relatively little about these patterns in Canada. Past Canadian studies focused primarily on intermarriage in terms of ancestry, for example intermarriage among people of British, Irish, or Ukrainian origin (Kalbach, 1983, Kalbach, 2002, Richard, 1991), or on intermarriage in terms of the place of birth (Canadian-born versus foreign-born; Tzeng, 2000). Lee and Boyd's (2008) recent work is an exception in that they focus on interracial couples; they, however, restrict their analysis solely to unions involving Canadians of an Asian origin.

The lack of studies on interracial couples in Canada is surprising given the fact that Canada is an immigration country and that an increasing number of immigrants are coming from non-European countries. In 2001, 18 per cent of Canada's population was foreign-born (Statistics Canada, 2003b) - a percentage 1.6 times higher than that in the United States (Camarota, 2002) and one of the highest 
in Canadian history. At the turn of the century, 73 per cent of immigrants who came to Canada in the 1990 s were classified as belonging to a visible minority group (Statistics Canada, 2003a).

The absence of research on racially mixed conjugal couples can be partly explained by the lack of appropriate data as Canadian statistics do not traditionally collect information on race but only on ethnic origin, immigration status or place of birth. Data on the ethnic origin are unfortunately of limited use, given that a large proportion of respondents declare multiple ancestries or use the category 'Canadian' (Pryor et al., 1992). However, despite the fact that Canadian statistics do not work with the concept of race, more recent censuses and surveys introduced the concept of 'visible minority' that designates 'persons, other than Aboriginals, who are nonCaucasian in race or non-white in skin colour' (Department of Justice Canada, 1995).

In this paper, we use the opportunity offered by the 2001 micro-detailed Census data to analyse unions between visible minorities and non-minority individuals (i.e. 'White' - 'non-White' unions). Furthermore, we consider the importance of mother tongue as linguistic issues play a prominent role in Canada, especially in the French province of Quebec. Our definition of race and interracial unions is based on self-declared status, i.e. we consider a union to be interracial if one of the partners reported a non-minority status and the other declared a visible minority status. We focus on the simple question of how common these unions are and which visible minorities are more likely to enter into a union with Whites. Our effort should not be understood as an attempt to build a comprehensive picture of 
racial assortative mating in Canada. It should rather be viewed as a step towards a better understanding of interracial unions.

Specifically, we are interested in variations across three Canada's gateway cities: Montreal, Toronto, and Vancouver. These metropolitan areas were selected for three reasons. First, about 75 per cent of immigrants and 73 per cent of visible minorities reside in these areas (Hou and Picot, 2004), and their minority populations are large enough to make the analysis possible. Second, given the high concentration of visible minorities in these three metropolitan areas, our analysis provides a rather accurate picture of interracial unions in Canada as a whole. Finally, using metropolitan areas as a unit of analysis will help us to avoid making untenable assumptions about the existence of one Canada-wide marriage market (Harris and Ono, 2005).

\section{Interracial conjugal unions, social boundary, and social integration}

Research on assortative mating, i.e. how much spouses resemble each other, has a long tradition in social sciences as the levels of intermarriage are often used to characterize the patterns of social stratification, openness of the society, and boundaries of social groups. Homogamy (endogamy) refers to couples who share similar characteristics. Heterogamy (intermarriage, exogamy) describes unions between individuals who are dissimilar in the given trait. There is a vast body of research that investigates homogamy with respect to religion (Johnson, 1980), immigration status (Tzeng, 2000, Meng and Gregory, 2005), education (Mare, 1991, Hamplova, 2009, Hamplova and Le Bourdais, 2008), occupation (Smits et al., 1999), 
race (Harris and Ono, 2005), ethnicity (Kalbach, 2002), or a combination of these characteristics (Qian and Lichter, 2007, Blossfeld and Timm, 2003).

In immigration countries like Canada, Australia or the United States, analyses of interracial/interethnic marriage occupy a special position within this tradition because racial intermarriage has wide implications regarding the integration of ethnic and racial minorities (Qian and Lichter, 2007, Alba and Nee, 2003). Intermarriage is often considered to be both a sign of minorities' assimilation and an engine of further integration. The former process refers to the fact that intermarriage is a visible manifestation of inter-ethnic contacts. It signals that individuals of different backgrounds no longer perceive social and cultural differences to be significant enough to prevent them from forming a long-term intimate union (Gordon, 1964, see Alba and Nee 2003). The latter process views intermarriage not as a sign of already completed integration but rather as a vehicle leading towards assimilation. Through intermarriage, minorities are expected to acquire customs of the mainstream culture that are important for achieving success in the host society (Meng and Gregory, 2005).

Note, however, that although intermarriage is important for understanding interracial relations, it should not be unquestionably taken as a sign of full integration. Song (2009) reminds us that high levels of intermarriage are not necessarily accompanied by integration in all domains of life. For example, Black Britons highly intermarry with Whites but a significant portion of them are not economically integrated. Moreover, as Song argues intermarriage does not 
automatically produce the loss of ethnic identity. On the contrary, racial awareness might be heightened by direct contact with a member of another racial group.

\section{Interracial conjugal unions across Canadian gateway cities}

Before we elaborate hypotheses about factors that are likely to be associated with racial exogamy, we briefly summarize the history of Canadian immigration. The racial and ethnic composition of the Canadian population is shaped by the fact that, aside from the Aboriginals, everyone in Canada is an immigrant or an offspring of immigrants. The country was established by the French and British and these two groups represented around 90 percent of the population up to the end of the $19^{\text {th }}$ century (Driedger, 1996). We must also note that Blacks lived in Canada from the very beginning of the European settlement. Yet, their history significantly differs from that of their U.S. counterparts. Slavery was nearly non-existent in Canada and most Blacks came to the country voluntarily, often escaping from the United States and West Indies (Tulloch, 1975, Hepburn, 2007, Winks, 1971).

Throughout the first half of the $20^{\text {th }}$ century, the European immigration became more diverse but non-European immigration was highly restricted. Most of the existing restrictions were lifted in the early 1960s and, in 1967, a point-based "colour-blind" system focusing on the immigrants' human capital was introduced (Kelley, 1998). Consequently, the proportion of non-White immigrants increased dramatically. 


\subsection{Hypotheses}

In this section, we formulate four hypotheses about factors that might be associated with racial intermarriage in Canada. First, past research has shown that the rates of interracial unions vary across racial groups and that some minorities partner outside their own circle more easily than others.

Accordingly, we expect that various visible minority groups in Canada have different tendencies to partner with Whites. However, the relative distance separating the groups is probably not the same as it is in other countries. For example, Blacks - who have the lowest rates of intermarriage in the United States (Harris and Ono, 2005, Qian and Lichter, 2001) - have had a different historical experience in Canada. Simple descriptive statistics indeed suggest that a relatively high proportion of them lives in mixed unions (Milan and Hamm, 2004).

Second, we expect to find significant variations across the three metropolitan areas (Montreal, Toronto, and Vancouver). The frequency of interracial conjugal unions in any given city is likely to be strongly influenced by the size of the particular visible minority populations (Qian and Lichter, 2007, Davison and Widman, 2002, Qian and Lichter, 2001). To understand the effect of the population size on interracial unions, we need to distinguish between its 'numerical' and 'substantial' effect. While the latter speaks about different propensity to partner outside of one's own group, the former points to the fact that a larger group has larger marginal totals (because of group size, the frequencies in the given rows and columns are large). Consequently, the cell referring to homogamous couples will be larger for more numerous groups even if there is no association between the row and 
column variables (Powers and Xie, 2000). In other words, as population size grows, the number (and proportion) of homogamous couples increases even if the pairing with respect to race is completely random.

Reflecting this statistical property, we expect that the observed percentage of White/non-White unions will be smaller for larger groups and in the metropolitan areas with the larger visible minority population. However, the relationship between the size of the population and racial exogamy may not hold once we control for the group size. In fact, the association between the size of the minority population and exogamy could be reversed once a multivariate method is applied (Qian and Lichter, 2007).

Third, we expect that Montreal - as a part of the French province of Quebec - is likely to exhibit weaker predisposition towards interracial partnerships. Traditionally, French Canadians have displayed lower levels of marital exogamy (Hurd, 1964, Kalbach, 2002, Richard, 1991), and recent surveys show that Quebecers still hold less positive attitudes towards immigrants and racial intermarriage (Girard, 2008). In contrast, we predict that Vancouver will display the highest tendency towards interracial pairing, as the West has been multicultural and multilingual throughout its past and no single ethnic group ever had a majority (Driedger, 1996).

However, Montreal's weaker tendency towards interracial pairing could be attenuated by other factors. Quebec has specific immigration policies that might affect minorities' integration. For example, Quebec is the only province in Canada that has the right to pre-select immigrants best suited for living in its francophone 
society. Moreover, this province rejected Canadian 'multiculturalism' (Nugent, 2006) and adopted a policy of 'inter-culturalism' whose goal is to integrate minorities into the francophone 'nation québécoise' (Labelle et al., 1995). Given the fact that the linguistic issues are given a prominent - and arguably even increasing role in defining the cultural boundaries and delimiting the 'nation québécoise' (Elliot and Fleras, 1992), interracial/interethnic barriers might be weakened among French speaking minorities.

Finally, we acknowledge that immigration status and differences between Canadian-born and foreign-born visible minorities constitute another important factor that needs to be taken into consideration. The immigration status of individuals is likely to influence both the levels and the patterns of interracial assortative mating. The former points to the fact that immigrants tend to intermarry to a different extent than native born visible minorities (Qian and Lichter, 2007, Qian and Lichter, 2001). The latter suggests that the relative proximity of racial groups might vary depending upon whether the individual is an immigrant.

\section{Data and method}

To compare White/non-White unions in Montreal, Toronto, and Vancouver, we used the 20 per cent analytic sample from the 2001 Census available in Research Data Centers (RDC). As Statistics Canada did not provide a family file, we used the individual-level data and linked couples together. In total, we retrieved information 
on 97.6 per cent of respondents who were identified as opposite-sex spouses or cohabitors ${ }^{1}$.

Only couples living in Montreal, Toronto, and Vancouver and couples where none of the partners declared multiple visible minority status, 'minority n.i.e' (not included elsewhere) or aboriginal status, were selected for the analysis. Individuals with multiple minority statuses were left out as it is not clear what 'intermarriage' stands for in their case. Aboriginals were not included for three reasons. First, they are not classified among visible minorities (Department of Justice Canada, 1995). Second, we analyse variation across immigration status, which does not apply to the First Nations. Finally, they often live on reserves, which might restrict their access to partners from other racial groups. Furthermore, we selected only individuals who were born in Canada or immigrated before age seventeen. Those who migrated at a later age might have formed a union before they arrived to Canada.

In total, information on 235,457 couples is available $(109,245$ couples in Montreal, 85,848 in Toronto, and 40,364 in Vancouver). After reporting descriptive statistics and distribution of interracial couples, we turn our attention to log-linear models. This method distinguishes between patterns that result from the marginal distributions of the male and female characteristics (i.e. the relative size of their racial group), and those that reflect the association between the partners' traits (Mare, 1991, Powers and Xie, 2000).

\footnotetext{
${ }^{1}$ Our sample does not include higher order couples in multiple family households.
} 


\section{Results}

\subsection{Descriptive statistics}

The 2001 Census distinguishes ten visible minority groups: Chinese, South Asians ${ }^{2}$, Blacks $^{3}$, Filipinos, Latin Americans ${ }^{4}$, South East Asians ${ }^{5}$, Arabs ${ }^{6}$, West Asians ${ }^{7}$, Koreans, and Japanese (sorted by the size of the population in descending order). Table 1 reports the percentage of the total population of Montreal, Toronto and Vancouver that each group represents. The table shows that Vancouver has the highest proportion of visible minorities (35 per cent of Vancouver men and 36 per cent of Vancouver women), followed closely by Toronto (34 per cent of men and 35 per cent of women). In contrast, Montreal has the smallest visible minority population (13 per cent of men and women). In Vancouver, over 80 per cent of visible minorities are Asians. In contrast, Asians represent only approximately 35 per cent of the non-White population in Montreal and around 65 per cent in Toronto.

$<$ Table $1>$

The left part of Table 2 shows the total percentage of visible minority individuals who live with a partner from a different group (all interracial couples).

\footnotetext{
${ }^{2}$ East Indians, Bangladeshis, Pakistanis etc.

${ }^{3}$ Jamaicans, Blacks, Somalis, etc.

${ }^{4}$ Spanish, Latin/Central/South Americans, Mexicans, etc.

${ }^{5}$ Vietnamese, Cambodians, etc.

${ }^{6}$ Arabs, Lebanese, Iraqis, etc.

${ }^{7}$ Iranians, Afghans, West Asians.
} 
The middle part gives the same statistics, after excluding all couples comprising an immigrant who arrived to Canada after age 16. Finally, the right part of the table reports the percentage of White/non-White couples among this restricted sample.

$<$ Table 2>

The expectation that the percentage of interracial couples is inversely related to the size of the minority population is confirmed only for men. The highest proportion of inter-partnered men is indeed in Montreal which has the smallest nonWhite population. In this city, around 16 per cent of married or cohabiting nonWhite men live with a spouse of a different racial status. In contrast, only approximately 9 per cent of their counterparts in Toronto and Vancouver are in interracial unions. The inverse relationship between the size of population and the proportion of men in interracial couples is more evident if we leave out immigrants who arrived to Canada after age sixteen ( 48 per cent in interracial unions in Montreal, 40 per cent in Toronto, 38 per cent in Vancouver). However, the same conclusion cannot be drawn for women as the percentage of those living in interracial unions is nearly as high in Vancouver as it is in Montreal.

We already argued that percentages are not a very good measure of association because they are partly determined by the number of men and women in the given racial category. Therefore, we turn to log-linear models to estimate the number of exogamous unions, net of the population size. 


\subsection{Log-linear models}

To estimate the log-linear models, the data were cross-classified into a five-way table $^{8}$ : man's visible minority status $\mathrm{x}$ woman's visible minority status $\mathrm{x}$ man's immigration status $\mathrm{x}$ woman's immigration status $^{9} \mathrm{x}$ metropolitan area. Model specification and corresponding fit statistics are reported in Table 3. Model selection is based on BIC statistic.. Generally, a negative BIC signifies that the model replicates the pattern in the table adequately and the more negative BIC is, the better the fit of the model (Raftery, 1995). Below, we briefly describe how we selected the model that will be used for interpretation.

Model 1 in Table 3 serves as a baseline for evaluation. It controls for the number of men and women in the racial categories in the selected metropolitan areas and their immigration status, and it includes dummies controlling for originally empty cells (see footnote 10). Furthermore, this model saturates the overall interaction between man's and woman's race, i.e. posits that there is some general

\footnotetext{
${ }^{8}$ The minority status is classified into eleven categories (visible minorities + 'White'). Immigration differentiates immigrants from non-immigrants. City designates Montreal, Toronto, or Vancouver. This cross-classification produced a table with 1,452 cells. As some cells in the table were empty, we imputed them with a constant (0.5). None of these empty cells are among the cells with the minority/White couples.

${ }^{9}$ Refers to immigrants who arrived to Canada before age 17.
} 
resemblance between men's and women's race but holds this resemblance constant across cities and immigration status. ${ }^{10}$

Model 2 tests whether the overall tendency towards racial intermarriage differs across these three cities. Its fit statistics confirm this expectation (BIC dropped by 980.3). Therefore, we must conclude that the odds of crossing a racial barrier significantly differ depending on whether a couple lives in Toronto, Montreal, or Vancouver. Model 3 considers the effect of the immigration status of the couple. Another dramatic decrease in the BIC confirms that the relative similarity of the partners' immigration status is highly significant (BIC: -600.0 versus $-12,414.7)$. Model 4 tests whether the effect of being an immigrant varies across cities. As the BIC statistic drops again (from -12,414.7 to -14,146.9), we must conclude that the gap between immigrants and non-immigrants depends on whether they live in Montreal, Toronto, or Vancouver.

$<$ Table $3>$

${ }^{10}$ The strategy to include the overall interaction is appropriate if our main interest is to show differences in the association as it allows us to focus on similarity or dissimilarity. This will also help us to take care of associations that are not the focus of our interest. 
group-specific parameters instead of one single overall parameter. This will allow us to estimate odds of intermarriage for each minority group separately.

Models 5 to 7 are direct replications of Models 2 to 4 but account for differences across visible minority groups. Again, we started by testing differences across cities and then continued with differences across immigration statuses. As the modeling strategy and conclusions derived above also hold for this part of the analysis (see Table 3), we do not go through detailed comments. It suffices to say that the effect of nativity and place of residence is not the same for all visible minority groups.

In the last step, we checked whether all the higher order interaction terms are still significant. As the odds of intermarriage for couples formed by two immigrants did not significantly vary across cities, this three-way interaction was taken out. However, the odds for couples of two native born Canadians remained different in each metropolitan area. This model (Model 8) shows the best fit of all models that measure group-specific propensity towards marrying outside one's own group.

Four conclusions can be drawn from the fit statistics of the log-linear models presented here. First, residents of Montreal, Toronto, and Vancouver differ with respect to the odds of living in interracial unions. Second, different visible minority groups face different odds of forming a union with a White partner. Third, groupspecific odds of intermarriage with Whites vary across the cities. Fourth, immigration status matters but its effect is not the same for all minorities and in all metropolitan areas. 


\section{$\underline{4.3 . ~ I n t e r p r e t a t i o n ~ o f ~ p a r a m e t e r s ~ f r o m ~ M o d e l ~} 8$}

Table 3 informs us about factors that are significant but it does not tell us anything about the strength and the direction of the effects; nor does it say how these results relate to our hypotheses. In the next step, we therefore focus on the estimated parameters from Model 8. As we need to consider seventy parameters and their combinations to get a full grasp of the patterns describing racial heterogamy, we do not present the parameters themselves. Instead, we report the estimated number of White/non-White couples for 1,000 homogamous couples within the category sorted by the couple's immigration status and the place of residence (see Table 4). We must note that these values represent the estimated number of White/non-White unions after controlling for the size of the respective populations.

Model 8 confirms our first hypothesis that different visible minorities in Canada face different odds of forming a union with a White person. If we look at the total number of heterogamous couples (irrespective of their immigration status and metropolitan area), we find that Blacks, Chinese, and Latin Americans display the highest odds of inter-partnering with a White person. If we calculate averages across metropolitan areas and immigration status ${ }^{11}$, we estimate an approximate number of 73 Black/White, 51 Chinese/White, and 47 Latino/White couples for 1,000

\footnotetext{
${ }^{11}$ We can illustrate this process with an example of Black/White couples. The estimated number of Black/White couples is $661(42+35+124=201$ in Montreal, $83+25+91=199$ in Toronto, and $127+29+105=261$ in Vancouver). Each of these numbers relates to 1,000 homogamous couples in the given category. Thus, the total of 662 relates to the 9 subgroups ( 3 in Montreal, 3 in Toronto, and 3 in Vancouver). As $662 / 9=73.4$, we estimate 73 Black/White couples per 1,000 homogamous unions on average.
} 
homogamous couples. In contrast, Koreans and West Asians have the lowest odds of crossing a racial boundary and we estimate that only approximately 15 Korean/White and 11 West Asian/White unions are found per 1,000 endogamous couples.

The high level of exogamy noted for Blacks in Canada stands in clear contrast with the findings from the United States. However, as we already mentioned, the U.S. and Canadian Blacks did not share the same historical experience (see section 2). Our finding also corroborates other studies that suggest that the low levels of Black-White unions found in the United States are not universal. For example, Model and Fisher (2002) showed that Blacks living in England are significantly more likely to have a White partner than their U.S. counterparts. Similarly, Muttarak (2004) showed that Black Caribbeans have the highest intermarriage rates among all British non-White groups.

Our second hypothesis suggested that different visible minority groups might face different odds of interracial pairing depending on whether they live in Montreal, Toronto, or Vancouver. Let us first ignore the variation across immigration status and focus on the total number of heterogamous couples in the three cities. Our data suggest that the Blacks' higher tendency to partner with Whites is general and applies to all three metropolitan areas. However, the relative position of other groups varies widely. In Montreal, Blacks are followed by non-Asian groups (Latinos and Arabs) with regards to forming a union with a non-minority partner. Averaging across immigration status, our model predicts 67 Black/White unions, 63 Latino/White unions, and 48 Arab/White unions per 1,000 homogamous couples in 
Montreal. In Toronto and Vancouver, Blacks are followed by Asian groups. In Toronto, for instance, our model estimates 66 Black/White, 49 Chinese/White, and 47 South Asian/White (closely followed by 46 Latino/White) unions per 1,000. In Vancouver, we predict 87 Black/White, 66 Chinese/White, 61 Filipino/White, and 60 Japanese/White couples per 1,000 (averages across immigration statuses).

$<$ Table $4>$

We also hypothesized that the tendency towards racial heterogamy might depend on the population size of the given visible minority in each area. We found that some Asian groups (Chinese, Japanese) are more likely to interpartner in Vancouver where they represent a larger portion of the population than in Montreal and Toronto (see Table 4). However, the same principle does not apply to all groups, in particular to Blacks. In Vancouver, only 0.99 per cent of male residents and 0.87 per cent of females are Blacks (see Table 1). In contrast, approximately 4 per cent of residents of Montreal and 6 per cent of Toronto's population declared a Black status. However, Black/White unions are proportionately more frequent in Vancouver than they are in Toronto.

Furthermore, we predicted that Montreal's population was likely to exhibit a generally weaker predisposition towards interracial heterogamy than the residents of the other two cities. The easiest way to assess the overall levels of heterogamy in these cities is to consider region specific odds of crossing a racial barrier derived from Model 2. The estimated value of the interaction term INTERMAR*CITY in Model 
2 was 0.441 for Toronto and 0.767 for Vancouver (estimates not reported in a table). This means that residents of Toronto and Vancouver have respectively 1.55 times and 2.15 times higher odds of forming a White/non-White union than Montreal's population $[\exp (0.441)=1.55 ; \exp (0.767)=2.15]$. This finding confirms our prediction about lower levels of White/non-White unions in Montreal. However, as we will show below, important variations exist across visible minority groups and immigration statuses (see also Figures 1a and 1b).

Let us first examine couples formed by two Canada-born individuals. In comparison to Montreal, couples living in Toronto have 2.67 times higher odds of being interracial and those living in Vancouver 3.36 higher odds of being so ${ }^{12}$. After controlling for the size of the population and averaging across racial groups, we estimate the average number of White/non-White couples to 13 per 1,000 in Montreal, 36 in Toronto, and 45 in Vancouver. Figure 1a suggests that this trend applies to all groups except Arabs who have higher odds of partnering with Whites in Montreal than in Vancouver ${ }^{13}$.

$<$ Figure $1 \mathrm{a}$ and $1 \mathrm{~b}>$

The picture is however quite different if we look at unions involving at least one immigrant (not born in Canada but arrived before age 17). When considering

\footnotetext{
${ }^{12}$ These estimates are based on the total sums of the estimated heterogamous couples. For example, the sum of the $1^{\text {st }}$ and $4^{\text {th }}$ column in Table 4 is 134 and $358(358 / 134=2.67)$

${ }^{13}$ The figure suggests that the same applies to Koreans and Latinos. However, their odds ratios are close to 1 .
} 
unions formed by an immigrant and a non-immigrant ('mixed immigration status'), Montreal's couples have 1.31 times higher odds of racial inter-partnering than those living in Toronto (see Figure 1b) and 1.18 times higher odds than their counterparts from Vancouver. The high levels of racial heterogamy observed among these couples in Montreal must however be interpreted in the light of the fact that Montreal's residents have significantly lower odds of entering a union with an immigrant. In other words, native born Quebecers are less likely to enter a conjugal union with an immigrant but once they do so, they are more open to cross an interracial barrier.

The conclusion that Montrealers who marry or cohabit with an immigrant are more likely to enter an interracial union than similar couples in Vancouver and Toronto also holds for unions of two immigrants. An immigrant marrying or cohabiting with another immigrant who lives in Montreal has 1.23 times higher odds of crossing the divide between Whites/non-Whites than his/her counterpart living in Toronto and 1.16 times higher odds of doing so than one residing in Vancouver. We suggest that the relatively high inclination of two-immigrant couples towards racial heterogamy in Montreal is partly a consequence of the low propensity of French Canadians to marry or cohabit with an immigrant. As immigrants are 'pushed out' of the native conjugal market, they are 'pushed towards' unions with other immigrants, including those of different racial origins. 
It is also instructive to look at visible minority groups separately (see Figure $1 b)^{14}$. When restricting the analysis to unions involving at least one immigrant, 7 out of 10 minority groups are found to be more likely to cross the racial boundaries in Montreal than in Toronto. Similarly, 6 out of 10 groups have higher odds of having a White partner if they live in Montreal than in Vancouver. This effect is the strongest for Arabs and South-East Asians, i.e. among groups that exhibit the highest proportion of French-speaking immigrants (see section 5.4 for the effect of language).

The previous paragraphs concentrated on differences across the metropolitan areas and on how these differences are influenced by immigration status. We can consider the same data using a different perspective, and focus more closely on the effect of the immigration status itself (see Figures 2a-2c and Table 4). Our fourth hypothesis predicted that the patterns of racial exogamy might largely differ depending on whether the individual is an immigrant or not. Our analysis confirms this prediction. First, significant differences are found in the total number of 'White' - 'non-White' couples within each immigration status (see Table 4). Unions made up of an immigrant and a non-immigrant (mixed immigration status) have the highest odds of being interracial, while unions between two immigrants are generally the least likely to be racially heterogamous. To illustrate this result, we

\footnotetext{
${ }^{14}$ This figure concerns both couples with mixed immigration status and unions between two immigrants as Model 8 does not include a three-way interaction between HETEROG* вОTHIMMIG* CITY.
} 
again calculated the average number of White/non-White couples for each immigration status.

Our model estimates the number of racially heterogamous unions at 61 per 1,000 among couples with mixed immigration status; 31 among couples consisting of two native born; and 19 among unions between two immigrants (averages across the visible minority groups and metropolitan areas). However, Figures $2 \mathrm{a}-2 \mathrm{c}$ show that the population of Montreal significantly departs from this pattern. In this city, the native born couples are less likely to involve partners of different racial origins not only when compared to mixed immigrant couples but also in comparison with unions between two immigrants.

$<$ Figures $2 \mathrm{a}-2 \mathrm{c}>$

Again, it is useful to consider variation across visible minority groups (see Figures $2 \mathrm{a}$ to $2 \mathrm{c}$ ). In all three cities, the immigration status exerts the strongest influence on the level of racial heterogamy for West Asians and Latinos. Furthermore, West Asians in Toronto and Vancouver and Latin Americans in Vancouver are exceptions to the rule that unions of two native born individuals tend to be more heterogamous than unions of two immigrants. Among these two visible minority groups, the lowest level of exogamy is found among those born in Canada who partnered with another native born Canadian. In contrast, Japanese in Toronto and Blacks and Chinese in Vancouver have higher odds of entering an interracial union if both spouses were born in Canada. 


\subsection{Language factor}

French language is an important factor in delimiting cultural boundaries in Quebec, and so we hypothesized that language should be one of the major factors influencing the odds of racial heterogamy in this province. French speaking minorities might be perceived as members of the wider 'French family' and the language might weaken the effect of race. The fact that immigrants from groups with the highest proportion of French native speakers (e.g. Arabs or South East Asians) tend to interpartner more easily in Montreal than in Toronto or Vancouver reinforces this hypothesis (see p. 21).

Ideally, we should have tested this hypothesis by adding the language dimension to our log-linear models. Unfortunately, this would require a seven-way table with at least 5,808 cells and our sample is not large enough to accommodate this type of analysis. To solve this problem, we merged all visible minorities into one group, i.e. we distinguish only between 'Whites' and 'non-Whites'. Furthermore, we created a new variable 'mother tongue' indicating whether an individual's mother tongue corresponds to the principal language in the area (i.e. French for respondents from Montreal and English for residents of Toronto and Vancouver). This variable will help us evaluate whether French Canadians are more inclusive of their language counterparts than English speakers are elsewhere in Canada.

We do not offer a detailed description of these models but only briefly present the main findings. We did not find any support for the thesis that French 
Canadians might be more inclusive of their linguistic counterparts than Anglophones elsewhere in Canada. The difference between Toronto's and Montreal's populations was not significant, i.e. non-White Francophones in Montreal do not mix more easily than non-White Anglophones in Toronto. Moreover, contrary to our prediction, non-White Anglophones in Vancouver were found to have odds of entering into a union with a White person that are approximately twice as high as their Francophone counterparts in Montreal.

\section{Conclusions}

Canada was the first country in the world to officially adopt a policy of multiculturalism. Its goal was the preservation of various cultures and harmonization of race relationships (Fleras and Elliot, 1992). The relative openness towards interracial conjugal unions might indicate that the policies promoting harmonious inter-racial interactions are successful. While racial intermarriage does not necessarily mean full acceptance of minorities (Song, 2009), it indicates an important weakening of the barriers between the groups and suggests a more hospitable environment for minority individuals.

Driedger (1996) argued that multiculturalism is most deeply rooted in the Canadian West. If multiculturalism encourages harmonious interracial relationships - and consequently also racial intermarriage - we should find the highest propensity to cross racial barriers in Vancouver. Our analysis confirms this expectation as odds of forming an interracial couple are indeed higher in Vancouver than in Toronto or Montreal. Toronto - a city that was historically uniformly Anglophone but has been 
actively encouraging multicultural policies for several decades - closely follows. Montreal seems to display the lowest openness towards interracial relationships, but this finding applies only to unions between two native born Canadians.

As we showed, the odds of crossing the White/non-White barrier vary across visible minority groups. Controlling for the number of men and women in a given visible minority, we found that Blacks have the highest odds of marrying a White person in Canada. In Toronto and Vancouver, Blacks are followed by Asian groups. In Montreal, the second and third positions are occupied by Latinos and Arabs. The fact that Blacks living in Canada have the highest levels of interracial pairing with Whites among all the visible minority groups stands in stark contrast with findings from the United States (Qian and Lichter, 2001, Harris and Ono, 2005, Heaton and Jacobson, 2000) but corresponds to the situation of Black Caribbeans in the UK (Song, 2009, Muttarak, 2004). This points out to important differences between these countries regarding their Black communities. If levels of exogamy reflect the strength of group boundaries and the degree of minority's integration, our analysis suggests that the Canadian - as well as the British - Black community is significantly more integrated compared to that in the United States.

Our principal analysis was supplemented by models describing the effect of mother tongue. If Quebec policy of pre-selecting immigrants who are likely to integrate into a francophone society is successful, French speaking visible minorities should intermarry more easily with French speaking Whites. However, our data do not confirm this hypothesis. On the contrary, we found that native born speakers of 
the majority language break the racial barrier more easily in Vancouver than in Montreal.

As pointed out at the beginning of the paper, this study did not attempt to identify all important factors that may affect the choice of one's partner. Rather, we aimed to document the levels of interracial pairing in Canada as a first step toward understanding the dynamic of interracial unions in this country. Nevertheless, our analysis raises interesting questions about the differences between the United States, Canada, and Great Britain. We believe that our finding regarding the high level of White/Black intermarriage is Canada is valid but it is possible that the relative position of other groups may be partly driven by differences in the racial classification used in each country.

For example, the studies from the United States use only four broad panethnic groups, while the Canadian classification distinguishes ten non-White categories. In the UK, the term black has traditionally referred to a wide category of non-Whites (Song, 2004). Even though more attention was paid to account for the diversity of the non-White population in recent years, the British ethnic groups still do not directly compare to the Canadian classifications. Moreover, the U.S. statistics merge all people originating from Europe, the Middle East or North Africa into a White category. In contrast, the Canadian classification separates those "Caucasian in race or white in skin colour" from West Asian or Arabs. These classification differences undoubtedly influence how racial endogamy is defined in each country and, consequently, the estimated levels of intermarriage. Clearly, more direct 
comparative research is needed to address this question. Its results should help us to better understand racial hierarchies in these societies. 


\section{References}

ALBA, R. \& NEE, V. 2003 Remaking the American Mainstream. Assimilation and Contemporary Immigration. Cambridge (MA): Harvard University Press.

BLOSSFELD, H.-P. \& TIMM, A. 2003 'Educational Systems as Marriage Markets in Modern Societies: A Conceptual Framework', in BLOSSFELD, H.-P. \& TIMM, A. (eds) Who Marries Whom? Educational Systems as Marriage Markets in Modern Societies. Dordrecht: Kluwer Academic Publisher.

CAMAROTA, S. A. 2002 'Immigrants in the United States - 2002'. Center for Immigration Studies.

DAVISON, J. D. \& WIDMAN, T. 2002 'The Effect of Group Size on Interfaith Marriage Among Catholics', Journal for the Scientific Study of Religion, vol. 41, pp. 397-404.

DEPARTMENT OF JUSTICE CANADA. 1995. 'Employment Equity Act'. Ottawa: Department of Justice Canada.

DRIEDGER, L. 1996 Multi-Ethnic Canada. Identities and Inequalities. Toronto: Oxford University Press.

ELLIOT, J. L. \& FLERAS, A. 1992 Unequal Relations. An Introduction to race and Ethnic Dynamics in Canada. Scarborough (ON): Prentice-Hall.

FLERAS, A. \& ELLIOT, J. L. 1992 Multiculturalism in Canada. Scarborough $(\mathrm{ON})$ : Nelson Canada.

GIRARD, M. 2008 'Résumé de résultats de sondages portant sur la perception des québécois relativement aux accommodements raisonnables, à l'immigration, aux communautés culturelles et à l'identité canadienne-française'. La Commission de consultation sur les pratiques d'accommodement reliées aux différences culturelles.

GORDON, M. 1964 Assimilation in American Life. New York: Oxford University Press.

HARRIS, D. R. \& ONO, H. 2005 'How many interracial marriages would there be if all groups were of equal size in all places? A new look at national estimates of interracial marriage', Social Science Research, vol. 34, pp. 236-251.

HEPBURN, S. A. 2007 Crossing the Border. A Free Black Community in Canada. Chicago: University of Illinois Press.

HOU, F. \& PICOT, G. 2004 'Visible minority neighbourhoods in Toronto, Montréal, and Vancouver', Canadian Social Trends.

HURD, B. 1964 Ethnic Origin and Nativity of the Canadian People. Ottawa: The Queen's Printer.

JOHNSON, R. A. 1980 Religious Assortative Marriage in the United States. New York: Academic Press.

KALBACH, M. A. 2002 'Ethnic Intermarriage in Canada', Canadian Ethnic Studies, vol. 34 , no. 2 , pp. $25-39$.

KALBACH, W. 1983 'Propensities for intermarriage in Canada as Reflected in the Ethnic Origins of Husbands and their Wives: 1961-1971', in ISHWARAN, K. (ed) Marriage and Divorce in Canada. Toronto: Methuen.

KELLEY, N. 1998 The Making of the Mosaic: A History of Canadian Immigration Policy. Toronto: University of Toronto Press. 
LABELLE, M., ROCHER, F. \& GUY, R. 1995 'Pluriethnicité, citoyenneté et intégration: de la souveraineté pour level les obstacles et les ambiguïtés', Cahier de recherche sociologique, vol. 25, pp. 213-245.

LEE, S. M. \& BOYD, M. 2008 'Marrying out: Comparing the marital and social integration of Asian in the US and Canada', Social Science Research, vol. 37, pp. 311-329.

MARE, R. D. 1991 'Five decades of Educational Assortative Mating', American Sociological Review, vol. 56, no. 1, pp. 15-32.

MENG, X. \& GREGORY, R. G. 2005 'Intermarriage and the Economic Assimilation of Immigrants', Journal of Labor Economics, vol. 23, no. 1, pp. 135-175.

MILAN, A. \& HAMM, B. 2004 'Mixed Unions', Canadian Social Trends.

MODEL, S. \& FISHER, G. 2002 'Unions Between blacks and whites: England and the US compared', Ethnic \& Racial Studies, vol. 25, pp. 728-754.

MUTTARAK, R. 2004 'Marital Assimilation: Interethnic marriage in Britain', Population and Society: Issues, Research, Policy. Canberra: Australian Population Association.

NUGENT, A. 2006 'Demography, National Myths, and Political Origins: Perceiving Official Multiculturalism in Quebec', Canadian Ethnic Studies, vol. 38, no. 3, pp. 21-36.

POWERS, D. A. \& XIE, Y. 2000 Statistical Methods for Categorical Data Analysis. San Diego: Academic Press.

PRYOR, E. T., et al. 1992 'Measuring ethnicity: Is 'Canadian' an evolving indigenous category?', Ethnic \& Racial Studies, vol. 15, no. 2, p. 214.

QIAN, Z. \& LICHTER, D. T. 2001 'Measuring Marital Assimilation: Intermarriage among Natives and Immigrants', Social Science Research, vol. 30, pp. 289312.

--- 2007 'Social Boundaries and Marital Assimilation: Interpreting Trends in Racial and Ethnic Intermarriage', American Sociological Review, vol. 72, pp. 68-94.

RAFTERY, A. 1995 'Bayesian Model Selection in Social Research', Sociological Methodology, vol. 25, pp. 111-163.

RICHARD, M. A. 1991 Ethnic Groups and Marital Choices. Vancouver: UBC Press.

SMITS, J., ULTEE, W. \& LAMMERS, J. 1999 'Occupational Homogamy in Eight Countries of the European Union, 1975-89', Acta Sociologica, vol. 42, pp. 55-68.

SONG, M. 2004 'Introduction: Who's at the bottom? Examining claims about racial hierarchy', Ethnic \& Racial Studies, vol. 27, no. 6, pp. 859-877.

--- 2009 'Is Intermarriage a Good Indicator of Integration?', Journal of Ethnic and Migration Studies, vol. 35, pp. 331-348.

STATISTICS CANADA. 2003a 'Canada's Ethnocultural portrait: The changing mosaic', 2001 Census: Analysis series. Statistics Canada.

--- 2003b 'Update on cultural diversity', Canadian Social Trends, Autumn, pp. 1923.

TULlOCH, H. 1975 Black Canadians. A long Line of Fighters. Toronto: NC Press. 
TZENG, J. M. 2000 'Ethnically Heterogamous Marriages: The Case of Asian Americans', Journal of Comparative Family Studies, vol. 31, no. 3, pp. 321337.

WINKS, R. W. 1971 Blacks in Canada: A History. Montreal: McGill University Press.

\section{CONTACT DETAILS:}

DANA HAMPLOVÁ is a research fellow at the Czech Academy of Science and an assistant professor in the Department of Sociology at Charles University.

ADDRESS: Institute of Sociology, Czech Academy of Science, Jilska 1, 11000 Praha 1, Czech Republic. Email: dana.hamplova@soc.cas.cz

CÉLINE LE BOURDAIS is Professor and Canada Research Chair in the Department of Sociology at McGill University.

ADDRESS: Department of Sociology, McGill University, 855 Sherbrooke Street West, Montreal (Quebec), Canada, H3A 2T7. Email: celine.lebourdais@mcgill.ca 
Table 1. Size of the visible minority populations in Montreal, Toronto \& Vancouver (per cent)

\begin{tabular}{|c|c|c|c|c|c|c|}
\hline & \multicolumn{3}{|c|}{ Men } & \multicolumn{3}{|c|}{ Women } \\
\hline & $\mathrm{M}$ & $\mathrm{T}$ & V & $\mathrm{M}$ & $\mathrm{T}$ & V \\
\hline Chinese & 1.48 & 8.80 & 17.02 & 1.56 & 8.82 & 17.54 \\
\hline South Asian & 1.83 & 10.51 & 8.33 & 1.52 & 9.75 & 8.03 \\
\hline Black & 3.94 & 6.15 & 0.99 & 4.17 & 6.92 & 0.87 \\
\hline Filipino & 0.41 & 2.53 & 2.45 & 0.61 & 3.18 & 3.31 \\
\hline Latino & 1.56 & 1.57 & 0.92 & 1.53 & 1.59 & 0.95 \\
\hline South East Asian & 1.18 & 1.15 & 1.37 & 1.12 & 1.12 & 1.44 \\
\hline Arab & 2.22 & 1.04 & 0.35 & 1.72 & 0.83 & 0.26 \\
\hline West Asian & 0.37 & 1.20 & 1.16 & 0.30 & 1.04 & 1.01 \\
\hline Korean & 0.11 & 0.89 & 1.40 & 0.11 & 0.92 & 1.51 \\
\hline Japanese & 0.05 & 0.37 & 1.07 & 0.07 & 0.40 & 1.36 \\
\hline Total minority & 13.15 & 34.22 & 35.07 & 12.71 & 34.58 & 36.28 \\
\hline Other* & 0.69 & 2.48 & 3.10 & 0.66 & 2.63 & 3.16 \\
\hline Non-minority & 86.16 & 63.30 & 61.84 & 86.63 & 62.78 & 60.56 \\
\hline $\mathrm{N}($ Total)** & 314,450 & 430,605 & 180,725 & 335,040 & 452,405 & 188,645 \\
\hline
\end{tabular}

Source: RDC 20\% Census 2001 Sample

* The category 'other' includes those who declared multiple visible minority status, 'minority n.i.e' or aboriginal status.

** Numbers were rounded to multiples of 5. 
Table 2. Proportion of racially mixed couples (per cent)*

\begin{tabular}{|c|c|c|c|c|c|c|c|c|c|}
\hline \multirow[b]{2}{*}{ Men } & \multicolumn{3}{|c|}{$\begin{array}{c}\% \text { of visible minorities in mixed } \\
\text { couples, all couples }\end{array}$} & \multicolumn{3}{|c|}{$\begin{array}{l}\% \text { of visible minorities in mixed } \\
\text { couples (restricted sample)*** }\end{array}$} & \multicolumn{3}{|c|}{$\begin{array}{c}\% \text { of visible minorities partnered } \\
\text { with non-minority individuals, } \\
\text { (restricted sample)** }\end{array}$} \\
\hline & Montreal & Toronto & Vancouver & Montreal & Toronto & Vancouver & Montreal & Toronto & Vancouver \\
\hline Chinese & 8.50 & 4.59 & 5.17 & 42.11 & 31.98 & 31.73 & 36.84 & 25.89 & 26.91 \\
\hline South Asian & 10.61 & 5.44 & 5.90 & 38.71 & 33.33 & 25.69 & 36.67 & 29.48 & 23.85 \\
\hline Black & 19.83 & 19.17 & 56.14 & 51.94 & 49.12 & 85.71 & 49.61 & 42.96 & 76.47 \\
\hline Filipino & 4.67 & 5.13 & 8.05 & 60.00 & 43.48 & 54.17 & 50.00 & 34.78 & 47.83 \\
\hline Latino & 25.48 & 20.86 & 27.42 & 52.17 & 46.38 & 45.00 & 48.94 & 40.00 & 36.84 \\
\hline South East Asian & 9.15 & 8.70 & 12.34 & 34.48 & 29.17 & 53.33 & 33.33 & 20.00 & 37.50 \\
\hline Arab & 20.68 & 18.60 & 31.25 & 53.19 & 54.55 & 28.57 & 48.94 & 47.83 & 19.35 \\
\hline West Asian & 20.88 & 12.56 & 13.48 & 0.00 & 28.57 & 50.00 & 0.00 & 26.67 & 37.50 \\
\hline Korean & 10.71 & 3.75 & 2.86 & 60.00 & 20.00 & 16.67 & 50.00 & 14.29 & 10.53 \\
\hline Japanese & 36.36 & 37.93 & 37.11 & 50.00 & 43.62 & 50.59 & 44.44 & 38.71 & 42.17 \\
\hline Total \% & 16.20 & 8.86 & 8.82 & 47.67 & 40.00 & 38.40 & 44.44 & 34.24 & 32.53 \\
\hline Women & Montreal & Toronto & Vancouver & Montreal & Toronto & Vancouver & Montreal & Toronto & Vancouver \\
\hline Chinese & 11.53 & 7.03 & 7.72 & 48.84 & 43.75 & 40.35 & 44.44 & 38.02 & 36.36 \\
\hline South Asian & 5.50 & 4.61 & 5.66 & 34.48 & 35.03 & 30.77 & 34.48 & 30.34 & 28.21 \\
\hline Black & 13.64 & 11.78 & 41.86 & 42.59 & 35.27 & 84.62 & 41.12 & 32.59 & 77.78 \\
\hline Filipino & 28.47 & 23.30 & 29.61 & 100.00 & 61.19 & 72.50 & 50.00 & 46.97 & 60.53 \\
\hline Latino & 26.22 & 23.27 & 37.93 & 48.84 & 45.59 & 52.17 & 44.19 & 41.79 & 47.83 \\
\hline South East Asian & 12.20 & 14.36 & 20.81 & 42.42 & 45.16 & 58.82 & 36.36 & 32.26 & 52.94 \\
\hline Arab & 8.33 & 7.62 & 17.95 & 37.84 & 38.89 & 33.33 & 36.11 & 29.41 & 33.33 \\
\hline West Asian & 10.13 & 6.11 & 4.94 & 25.00 & 31.25 & 42.86 & 0.00 & 25.00 & 28.57 \\
\hline Korean & 24.24 & 9.73 & 12.12 & 66.67 & 34.88 & 38.46 & 60.00 & 27.91 & 28.00 \\
\hline Japanese & 71.43 & 46.06 & 55.20 & 58.33 & 46.00 & 58.00 & 54.55 & 41.84 & 51.02 \\
\hline Total \% & 13.92 & 9.90 & 13.00 & 44.27 & 41.16 & 45.90 & 40.50 & 35.64 & 40.68 \\
\hline
\end{tabular}

* Percentages based on numbers rounded to multiples of 5.

** Native born + immigrants who landed in Canada before age 17.

Source: RDC 20\% Census 2001 Sample 
Table 3. Log-linear models of the association between man's and woman's visible minority status

\begin{tabular}{|c|c|c|c|c|}
\hline & & G2 & d.f. & $\mathrm{BIC}$ \\
\hline M1 & $\begin{array}{l}\text { MAN*CITY + WOMAN*CITY } \\
\text { MAN*IMMIGM + WOMAN*IMMIGW } \\
\text { IMMIGM*CITY + IMMIGW*CITY + } \\
\text { MAN*WOMAN + ZERO }\end{array}$ & $15,992.7$ & 1,262 & 380.3 \\
\hline M2 & M1 + INTERMAR*CITY & $15,673.9$ & 1,260 & -600.0 \\
\hline M3 & M2 + INTERMAR*BOTHNAT* BOTHIMMIG & $3,820.5$ & 1,257 & $-12,414.7$ \\
\hline M4 & M2 + INTERMAR ${ }^{*}$ BOTHNAT ${ }^{*}$ CITY + INTERMAR* BOTHIMMIG* CITY & $2,010.7$ & 1,251 & $-14,146.9$ \\
\hline M5 & $\mathrm{M} 1+\mathrm{HETEROG}^{*} \mathrm{CITY}$ & $15,433.6$ & 1,242 & -607.8 \\
\hline M6 & M7 + HETEROG* BOTHNAT + HETEROG* BOTHIMMIG & $3,384.0$ & 1,221 & $-12,386.2$ \\
\hline M7 & M7 + HETEROG* BOTHNAT*CITY + HETEROG* BOTHIMMIG*CITY & $1,559.1$ & 1,179 & $-13,668.6$ \\
\hline M8 & $\begin{array}{l}\text { M7 + HETEROG* BOTHNAT*CITY + HETEROG* BOTHIMMIG + } \\
\text { BOTHIMMIG* CITY }\end{array}$ & $1,612.3$ & 1,199 & $-13,873.7$ \\
\hline
\end{tabular}

MAN - man's race, WOMAN - woman's race, IMMIGM - man's nativity, IMMIGW - woman's nativity, CITY - place of residence, ZERO originally zero cells (now substituted by a constant 0.5 ), INTERMAR - union between a minority and non-minority person (1 parameter), HETEROG - union between a minority and non-minority person (10 group-specific parameters), BOTHNAT - union with both partners born in Canada, BOTHIMMIG - union with both partners immigrants 
Table 4. Estimated number of White/non-White unions per 1000 couples by metropolitan area and immigration status

\begin{tabular}{|c|c|c|c|c|c|c|c|c|c|}
\hline & \multicolumn{3}{|c|}{ Both native born } & \multicolumn{3}{|c|}{ Both immigrants } & \multicolumn{3}{|c|}{ Immigrant/Non-immigrant couples } \\
\hline & $\mathrm{M}$ & $\mathrm{T}$ & $\mathrm{V}$ & $\mathrm{M}$ & $\mathrm{T}$ & $\mathrm{V}$ & $\mathrm{M}$ & $\mathrm{T}$ & $\mathrm{V}$ \\
\hline Chinese & 20 & 62 & 93 & 21 & 20 & 24 & 69 & 66 & 80 \\
\hline South Asian & 8 & 39 & 49 & 21 & 26 & 18 & 62 & 75 & 54 \\
\hline Black & 42 & 83 & 127 & 35 & 25 & 29 & 124 & 91 & 105 \\
\hline Filipino & 9 & 31 & 51 & 9 & 26 & 33 & 27 & 76 & 98 \\
\hline Latino & 12 & 29 & 11 & 46 & 28 & 23 & 130 & 80 & 65 \\
\hline South East Asian & 7 & 12 & 21 & 13 & 5 & 9 & 79 & 31 & 53 \\
\hline Arab & 17 & 32 & 10 & 31 & 12 & 5 & 97 & 36 & 15 \\
\hline West Asian & 1 & 2 & 3 & 9 & 14 & 15 & 12 & 18 & 20 \\
\hline Korean & 10 & 17 & 9 & 10 & 7 & 6 & 32 & 22 & 20 \\
\hline Japanese & 9 & 51 & 79 & 17 & 10 & 20 & 68 & 39 & 82 \\
\hline
\end{tabular}

Source: RDC 20\% Census 2001 Sample 
Figure 1b: Odds ratios of living in a mixed conjugal union for couples of mixed immigration status or both immigrants

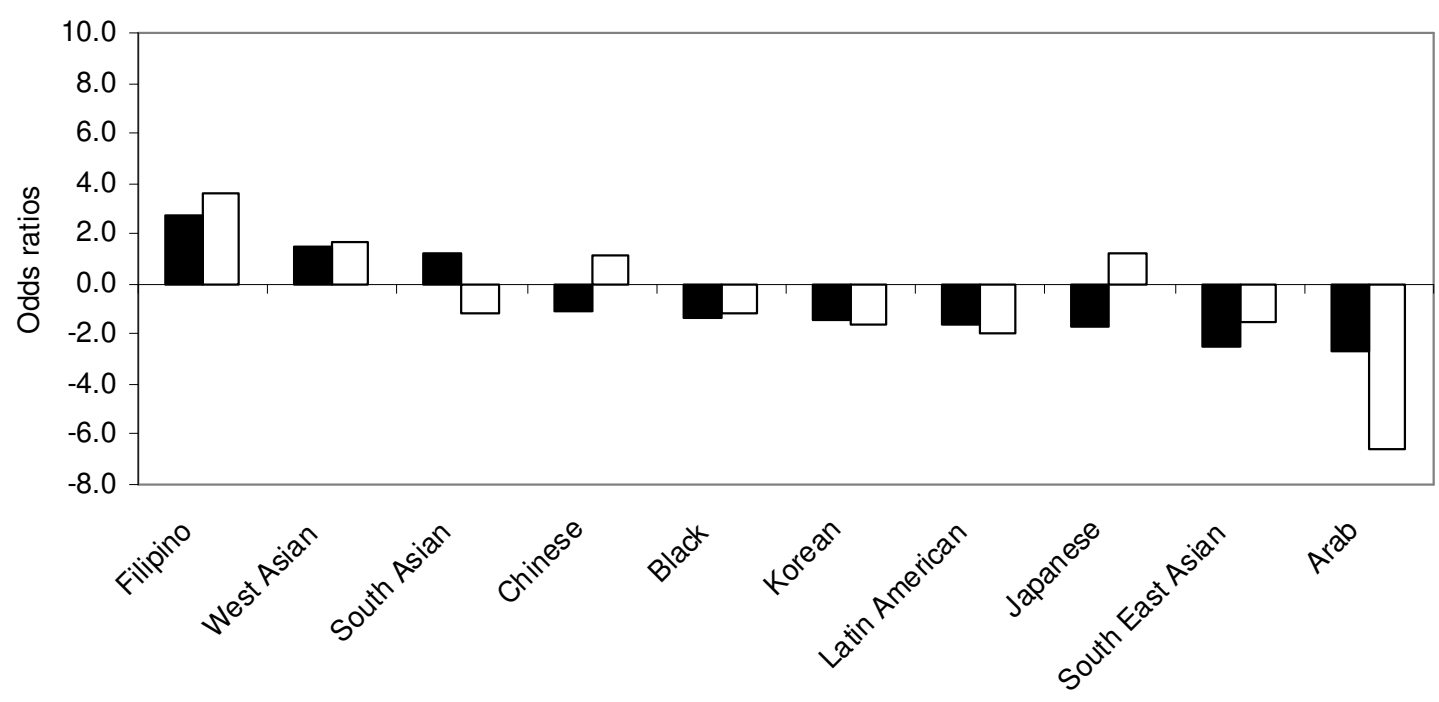

Toronto:Montreal $\square$ Vancouver: Montreal

URL: http://mc.manuscriptcentral.com/rers ethnic@surrey.ac.uk 

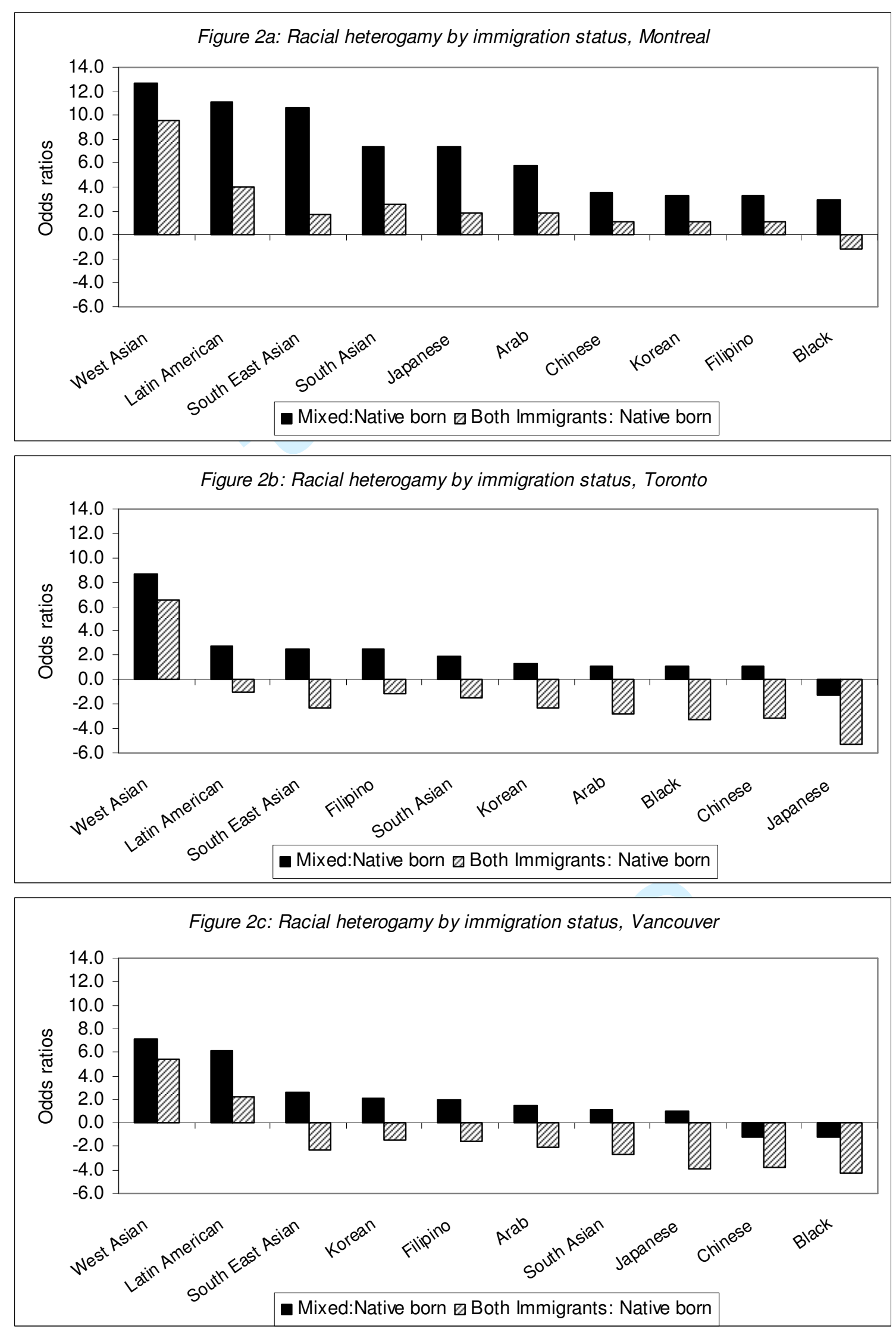

URL: http://mc.manuscriptcentral.com/rers ethnic@surrey.ac.uk 